\title{
Ontogenetic variations in dry mass and nucleic acid contents of Artemia salina
}

\author{
Toru Kobari ${ }^{1, *}$, ShigeKi Kori ${ }^{1} \&$ HARUKo Mori ${ }^{2}$ \\ ${ }^{1}$ Aquatic Sciences, Faculty of Fisheries, Kagoshima University, Shimoarata 4-50-20, Kagoshima, 890-0056, Japan \\ ${ }^{2}$ Aquatic Sciences, Graduate School of Fisheries, Kagoshima University, Shimoarata 4-50-20, Kagoshima, 890-0056, Japan
}

Received 3 April 2015; Accepted 8 December 2015 Responsible Editor: Kazutaka Takahashi

\begin{abstract}
We investigated ontogenetic variations in dry mass and nucleic acid contents of the planktonic crustacean Artemia salina. Individual contents of DNA and RNA increased exponentially with incubation day and developmental stage, except for newly-hatched nauplii. High variability was found in the temporal and ontogenetic patterns of dry (DW) and ash-free dry weights (AFDW) due to the mixture of different ages and stages, and thus RNA/DNA ratios were not significantly associated with weight-specific growth rates. RNA/DNA and AFDW/DNA ratios decreased from newly-hatched naupliar to middle post-metanaupliar stages, but AFDW/DNA ratios decreased while RNA/DNA ratios increased from late post-metanaupliar stages. These results suggest that nucleic acid ratios are not the optimal indicator for evaluation of weight-specific growth rates when there is high variability in body mass, but that a combination of RNA/DNA and AFDW/DNA ratios can be indicative of important stages in ontogenetic development, such as indicating yolk consumption of newly hatched nauplii and gonad maturation in late life stages of $A$. salina.
\end{abstract}

Key words: Artemia, DNA, dry mass, growth, RNA

\section{Introduction}

Zooplankton production rate can be defined as the change in biomass over a fixed period. This rate is often calculated as the product of biomass and the weight-specific growth rate of a zooplankton population or community (Kimmerer 1987). Biomass is generally determined through direct weight measurements or conversions from body length and/or biovolume (e.g., Postel et al. 2000). Weight-specific growth rates can be measured with continuous samplings (e.g., Heinle 1966), incubations (e.g., Burkill \& Kendall 1982, Kimmerer \& McKinnon 1983, Berggreen et al. 1988) and physiological models (Ikeda $\&$ Motoda 1978). Due to time-consuming procedures and practical limitations (Hirst \& McKinnon 2001, Hirst et al. 2005, Kimmerer et al. 2007, Kobari 2010), however, there is limited opportunity for direct measurement of weightspecific growth rate for natural populations and/or communities. Consequently, spatial and temporal resolutions of measurements are relatively low for estimating weightspecific growth in highly variable populations and com-

\footnotetext{
*Corresponding author: Toru Kobari; E-mail, kobari@fish.kagoshima-u. ac.jp
}

munities.

Over the last two decades, some biochemical approaches have been proposed as proxies for zooplankton growth measurements (e.g., Oosterhuis et al. 2000, Sastri \& Roff 2000, Wagner et al. 2001, Yebra \& Hernández-León 2004), since the quick procedures and good reproducibility enable more measurements. In particular, nucleic acid (i.e., DNA and RNA) methods can be theoretically applied over a range of taxa in zooplankton communities. Indeed, nucleic acid compositions have been suggested as an indicator of growth and nutritional condition in various crustacean species and life-stages (e.g., Dagg \& Littlepage 1972, Ota \& Landry 1984, Wagner et al. 2001, Gorokhova \& Kyle 2002, Becker et al. 2005, Yebra et al. 2005, 2011). As examples, RNA/DNA ratios could be a proxy for weightspecific growth rates (e.g., Wagner et al. 2001, Gorokhova \& Kyle 2002, Yebra et al. 2011), and individual body mass to DNA content ratios can be representative of cellular size (Gorokhova \& Kyle 2002). However, we have limited information on how nucleic acid contents are synchronized with development and growth over various life stages in crustaceans, such as what potential errors in growth rate measurements might be associated with discontinuous weight increments in molts or with egg production (Hirst 
et al. 2001, 2005).

In the present study, we investigated ontogenetic variations in directly measured body weights (dry mass and ash-free dry mass) and nucleic acid contents (DNA and RNA) of Artemia salina, as a model for crustacean zooplankton. The present results give information on the advantages and disadvantages of the nucleic acid method for evaluating crustacean development and growth.

\section{Materials and Methods}

\section{Incubation}

Resting eggs of Artemia salina (Spectrum Brands Japan) were hatched in a 1 -L flask filled with $0.2 \mu \mathrm{m}$-filtered seawater. The flask was aerated and kept in the dark at $28^{\circ} \mathrm{C}$ for 24 hours. The newly hatched nauplii were transferred to a 5-L polyethylene tank containing 3-L of the same filtered seawater. The density of newly hatched nauplii at the start of incubations was $\sim 2.0 \times 10^{4}$ animals $\mathrm{L}^{-1}$. The tank was maintained at $20^{\circ} \mathrm{C}$ on a $12 \mathrm{~L}: 12 \mathrm{D}$ cycle in an incubator (EYELA MTI-201B) and the seawater was gently aerated. The nauplii were fed a mixture of Isochrysis sp., Pavlova sp., Thalassiosira weissflogii and Tetraselmis sp. (Shellfish Diet $1800^{\mathrm{TM}}$ : Instant Algae Co.) with a flow-through system (Williamson et al. 1985). Our culture of $A$. salina was maintained at a phytoplankton concentration of $3.5 \times 10^{8}$ cells $\mathrm{L}^{-1}$ throughout the day, corresponding to more than $1.8 \times 10^{4}$ cells animal $^{-1}$. Since the culture was kept at higher concentrations than the maximum ingestion rate $\left(8 \times 10^{5}\right.$ cells animal ${ }^{-1}$ day $^{-1}$ for nauplii: Lavens \& Sorgeloos 1991), it should be sufficient for assessing their development and growth.

\section{Dry weight}

For measuring temporal changes of dry weight, animals ( 1 to 10 individuals) were arbitrarily sorted on a daily basis from the incubation tank. Note that different developmental stages were included within these subsamples. For determining ontogenetic patterns in dry weight, animals were picked from the incubation tank and classified into each developmental stage (following Criel 1991) using a dissecting microscope (Table 1). These animals were quickly rinsed with Milli-Q water and placed into a pre-weighed and pre-combusted aluminum pan. These samples were then dried at $60^{\circ} \mathrm{C}$ for 24 hours and stored in a dessicator for an additional 24 hours. Dry weight (DW) was measured with a microbalance (Sartorius SE2) to the nearest $0.1 \mu \mathrm{g}$. Following dry weight measurements, samples were combusted at $470^{\circ} \mathrm{C}$ for 4 hours using a muffle furnace (Advantec FUW220PA) and stored in a dessicator for 24 hours. Since ash-free dry weight (AFDW) was then the DW (inorganic plus organic contents) minus the weight of the ash (only inorganic contents) determined with a microbalance, AFDW was therefore the weight of the organic content of the sample.
Table 1. Developmental stages investigated in the present study (Criel 1991). TL: Total body length (mm). $\mathrm{N}_{\mathrm{DW}}$ should be subscript style. Number of animals for measuring dry weight. $\mathrm{N}_{\mathrm{NA}}$ should be subscript style. Number of animals for measuring nucleic acids.

\begin{tabular}{clrrr}
\hline Stage & & $\mathrm{TL}$ & $\mathrm{N}_{\text {DW }}$ & $\mathrm{N}_{\text {NA }}$ \\
\hline 1 & Nauplius I & 0.48 & 10 & 30 \\
2 & Metanauplius I-II & 0.90 & 10 & 30 \\
3 & Metanauplius III & 1.00 & 6 & 25 \\
4 & Metanauplius IV & 1.10 & 6 & 20 \\
5 & Post-metanauplius I & 1.29 & 4 & 15 \\
6 & Post-metanauplius II & 1.46 & 3 & 12 \\
7 & Post-metanauplius III & 1.61 & 3 & 10 \\
8 & Post-metanauplius IV & 1.75 & 3 & 8 \\
9 & Post-metanauplius V & 1.87 & 2 & 5 \\
10 & Post-metanauplius VI & 2.03 & 1 & 3 \\
11 & Post-metanauplius VII & 2.27 & 1 & 1 \\
12 & Post-larval & 2.45 & 1 & 1 \\
13 & Adult (egg-carrying) & 2.70 & 1 & 1 \\
\hline
\end{tabular}

\section{Nucleic acids}

RNA and DNA were measured with the microplate fluorescent assay (MFA) developed by Wagner et al. (1998). Wagner et al. (1998) modified the sequential fluorometric method to the MFA with 96-well microtiter plates by adopting a sarcosyl extraction technique and eliminating the DNase step, thus allowing application of the assay to small samples (single animals) without extending working time.

Animals for biochemical analysis (1 to 30 individuals) were picked from the incubation tank, placed into a $2-\mathrm{mL}$ vial and frozen at $-80^{\circ} \mathrm{C}$. Specimens in the vial were thawed and then homogenized by vigorous shaking with zirconia beads in $200 \mu \mathrm{L}$ of a $1 \%$ sarcosyl extraction buffer. The samples were shaken for 15 minutes at room temperature on a vortex mixer equipped with a multiplevial head. The samples were then diluted with $1.8 \mathrm{~mL}$ of $10 \mathrm{mM}$ Tris buffer to reduce the sarcosyl concentration to $0.1 \%$, and were then shaken for an additional 5 minutes. Finally, samples were centrifuged $(15000 \mathrm{~g})$ for 10 minutes to separate insoluble Artemia remains.

The measurement protocol for each run consisted of 2 supernatant aliquots $(100 \mu \mathrm{L}), 8$ replicate wells with 0.01 to $0.5 \mu \mathrm{g} \mathrm{mL}^{-1}$ DNA (calf-thymus, Sigma-Aldrich D4522) and 11 replicate wells containing 0.01 to $3 \mu \mathrm{g} \mathrm{mL}^{-1} \mathrm{RNA}$ (bakers-yeast, Sigma-Aldrich R7125) using 96-well microplates (Nunc). Reagent blanks consisted of zero concentrations of standard solutions (containing all chemicals but no animal homogenate). In this study, we used RiboGreen (Invitrogen R11491) as a fluorescent dye because it is sensitive to nucleic acids for small cladocerans (Gorokhova \& Kyle 2002). We added $100 \mu \mathrm{L}$ of $0.1 \%$ RiboGreen to each well, and the plates were kept at room temperature for $20 \mathrm{~min}$ utes. Sample fluorescence was then scanned (first scan) on a microplate reader (Perkin-Elmer, ARVO MX1420) with $485 \mathrm{~nm}$ (excitation) and $535 \mathrm{~nm}$ (emission) filters. RNase 
(10 $\mu \mathrm{L}$ of a $100 \mu \mathrm{g} \mathrm{mL}^{-1}$ solution) was then added to each well. The microplate was again kept at room temperature for 20 minutes before the next sample fluorescence scan (second scan). RNA concentrations $\left(\mu \mathrm{g} \mathrm{mL}^{-1}\right)$ were calculated as the differences between first (DNA+RNA) and second (DNA) scans, and the standard curve of RNA versus the fluorescence established from the first scan of the same plate. DNA concentrations $\left(\mu \mathrm{g} \mathrm{mL}^{-1}\right)$ were computed from the second scan and the standard curve of DNA versus fluorescence established at the second scan (RNase treated) of the same plate.

\section{Data analysis}

Cumulative growth rates $\left(\mathrm{G}: \mathrm{day}^{-1}\right)$ were calculated as the change of individual dry weight (DW: $\mathrm{mg}_{\text {individual }}{ }^{-1}$ ) and ash-free dry weight (AFDW: $\mathrm{mg}$ individual $^{-1}$ ) over the number of days between the beginning of the incubation (day 0 ) and time of the sample collection (day t). We also computed instantaneous growth rate $\left(\mathrm{g}: \mathrm{day}^{-1}\right)$ as the change of DW and AFDW between consecutive days (i.e., 1 day). Weight-specific growth rate was calculated as:

$$
\mathrm{G} \text { or } \mathrm{g}=\left[\ln \left(\mathrm{W}_{\mathrm{t}}\right)-\ln \left(\mathrm{W}_{0}\right)\right] / \mathrm{t}
$$

where $\mathrm{W}_{0}$ and $\mathrm{W}_{\mathrm{t}}$ corresponded to either DW or AFDW at given days, respectively.

Statistical tests were performed with Excel Statistics 2012 (SSRI Co., Ltd). For identifying developmental trends in nucleic acid contents (DNA and RNA), body masses (DW and AFDW) and their ratios with respect to length of incubation and life stages, significant correlations were identified with the Pearson product-moment correlation coefficient. For the correlation analyses, individual DNA and RNA contents were log-transformed due to their exponential increases. Regression curves were determined for non-transformed data on individual ash-free dry weight to individual DNA and RNA contents in order to understand how nucleic acid contents were associated with growth. For identifying discontinuous developmental changes in the ratios of nucleic acids ratios and body masses, significant differences in any two groups (i.e., nucleic acid ratios and body masses at the two different incubation days or life stages) were investigated using Welch's t-test.

\section{Results}

Temporal increase was found for DW with increasing incubation days $(\mathrm{r}=0.681, p<0.01)$, but the variation patterns were unclear due to the discontinuous increase and decrease with time (Fig. 1). AFDW also showed a temporal increase ( $\mathrm{r}=0.884, p<0.01)$, although discontinuous variations were still found. Individual contents of DNA and RNA increased exponentially during the incubation, with the exception of considerably lower DNA and higher RNA contents during the 2 days after egg-hatching compared with on and soon after Day 3 (Table 2). Significantly positive correlation was found for log-transformed individual contents of DNA ( $\mathrm{r}=0.790, p<0.01)$ and RNA ( $\mathrm{r}=0.706$, $p<0.01$ ) with respect to incubation length.

While ontogenetic increase was found for both DW $(\mathrm{r}=0.779, p<0.01)$ and AFDW $(\mathrm{r}=0.939, p<0.01)$, the discontinuous variability was more evident for DW (Fig. 2). Individual contents of DNA and RNA increased exponentially with development, excepting for considerably lower DNA and higher RNA contents during the first to second stages than during Stage 3 (Fig. 1, Table 2). These ontogenetic increases were significant for both log-transformed individual contents of DNA $(\mathrm{r}=0.775, p<0.01)$ and RNA $(\mathrm{r}=0.780, p<0.01)$.

AFDW increased logarithmically and became saturated at higher individual contents of DNA and RNA (Fig. 3). AFDW was fitted with the logarithmic curves of individual contents of DNA or RNA as follows.

$$
\begin{aligned}
\text { AFDW } & =0.009 \times \ln (\mathrm{DNA})+0.057 \\
\mathrm{r}^{2} & =0.749, p<0.01 \\
\mathrm{AFDW} & =0.004 \times \ln (\mathrm{RNA})+0.031 \\
\mathrm{r}^{2} & =0.569, p<0.01
\end{aligned}
$$

While discontinous variability was found for both the instantaneous growth rates estimated with dry weight $\left(\mathrm{g}_{\mathrm{DW}}\right)$ and ash free dry weight $\left(\mathrm{g}_{\mathrm{AFDW}}\right)$, the cumulative growth rates $\left(\mathrm{G}_{\mathrm{DW}}\right.$ and $\left.\mathrm{G}_{\mathrm{AFDW}}\right)$ increased logarithmically and became saturated at around 0.05 day $^{-1}$ (Fig. 4). Next, we compared instantaneous and cumulative growth rates estimated using dry weight $\left(\mathrm{g}_{\mathrm{DW}}\right.$ and $\left.\mathrm{G}_{\mathrm{DW}}\right)$ and ash free dry weight ( $g_{\text {AFDW }}$ and $\mathrm{G}_{\text {AFDW }}$ ) to RNA/DNA ratios (Fig. 5). $g_{D W}$ and $g_{A F D W}$ were uncorrelated with RNA/DNA ratios, ranging from -1.5 to $1.5 \mathrm{day}^{-1}$. While the temporal patterns of $\mathrm{G}_{\mathrm{DW}}$ and $\mathrm{G}_{\mathrm{AFDW}}$ were uncorrelated at lower RNA/DNA ratios ranging from -0.25 to 0.25 day $^{-1}$, the two metrics converged at around 0.05 day $^{-1}$ at higher RNA/DNA ratios. The Pearson correlation coefficient was not significant for either $g$ or $\mathrm{G}$ and the RNA/DNA ratios.

Individual contents of RNA compared to those of DNA (i.e., RNA/DNA ratios) were significantly higher during the first to second days, or the stages after egg-hatching, compared with those after Day 3 or Stage 3 (Welch's t-test, $p<0.05$ : Fig. 6 , Table 2). RNA/DNA ratios varied from 0.4 to 3.9 during the middle period of the rearing experiment (Day 3 to 17) or during the middle stages (Stage 3 to 8 ). The ratios then increased towards a maximum on Day 23 or Stage 12 before declining again. AFDW to individual DNA content (i.e., AFDW/DNA ratios) was higher on the first day or stage after egg-hatching than on the next day or stages (Welch's t-test, $p<0.05$ ). AFDW/DNA ratios ranged from 1.0 to 3.3 during the middle of the rearing experiment (Day 3 to 17) or during the middle stages (Stage 3 to 8), and then declined. 

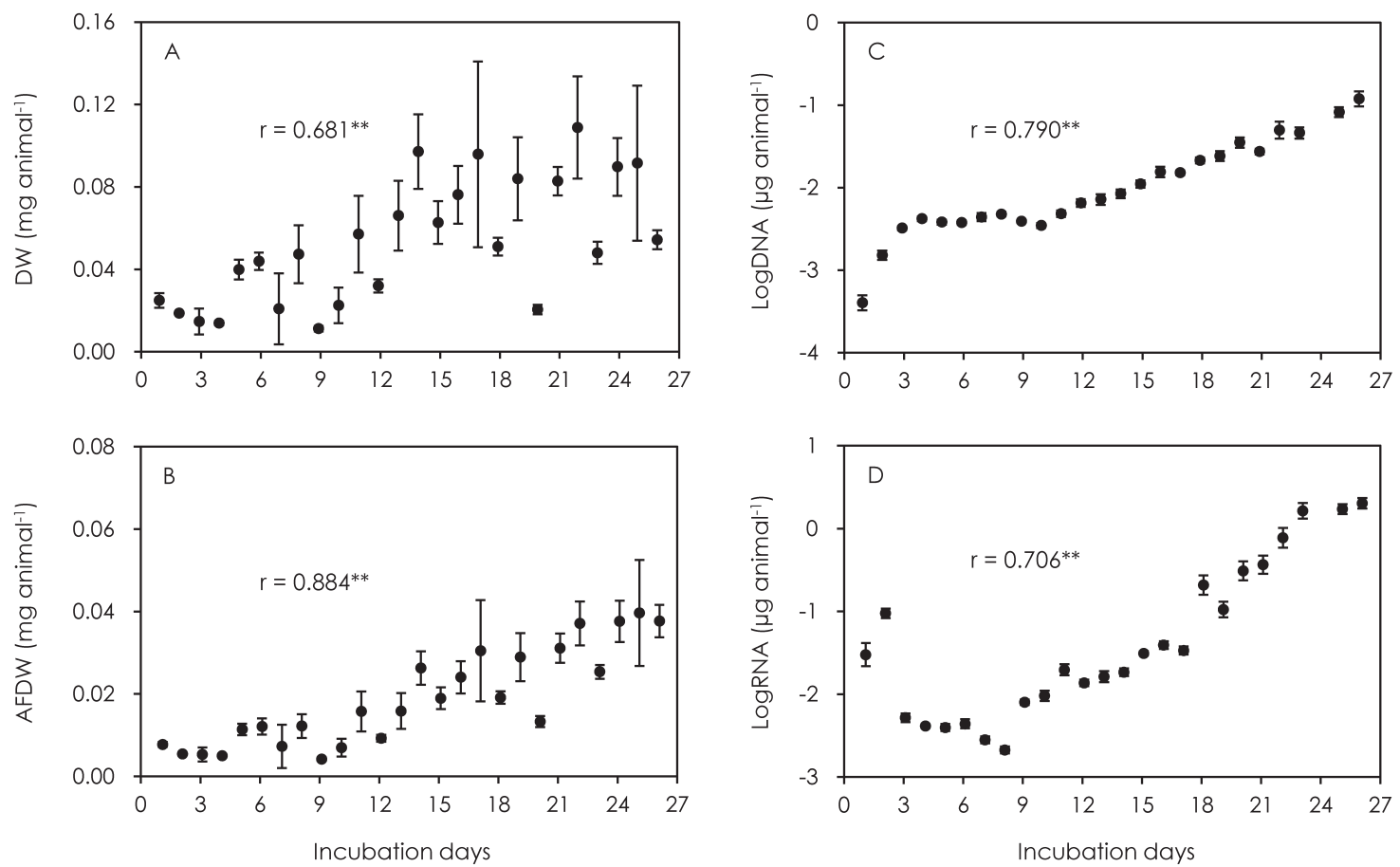

Fig. 1. Temporal changes in dry weight (DW: A), ash-free dry weight (AFDW: B), and individual contents of DNA (C) and RNA (D) of Artemia salina during incubation. Note that individual contents of DNA and RNA are log-transformed. Bars represent the standard error (SE) of the mean. r: Pearson correlation coefficient. ${ }^{* *}: p<0.01$.

Table 2. Summary of results for Welch's t-test of log-transformed individual contents of DNA and RNA and RNA/DNA ratios at first to second days or stages after egg-hatching compared to those on the next day (Day 3) or stage (Stage 3). DF: Degree of freedom.

\begin{tabular}{lrrr}
\hline & DF & \multicolumn{1}{c}{$\dagger$} & \multicolumn{1}{c}{$\mathrm{P}$} \\
\hline LogDNA & & & \\
Day 1 vs. Day 3 & 4.431 & -8.377 & 0.001 \\
Day 2 vs. Day 3 & 5.736 & -5.702 & 0.001 \\
& & & \\
Stage 1 vs. Stage 3 & 4.247 & -9.316 & 0.001 \\
Stage 2 vs. Stage 3 & 22.679 & -3.100 & 0.005 \\
& & & \\
LogRNA & & & \\
Day 1 vs. Day 3 & 4.773 & 3.418 & 0.019 \\
Day 2 vs. Day 3 & 7.327 & 13.213 & $<0.001$ \\
& & & \\
Stage 1 vs. Stage 3 & 4.802 & 4.137 & 0.009 \\
Stage 2 vs. Stage 3 & 21.973 & 2.891 & 0.008 \\
& & & \\
RNA/DNA & & & \\
Day 1 vs. Day 3 & 4.001 & 3.861 & 0.018 \\
Day 2 vs. Day 3 & 4.005 & 8.490 & 0.001 \\
& & & \\
Stage 1 vs. Stage 3 & 4.002 & 3.848 & 0.018 \\
Stage 2 vs. Stage 3 & 17.063 & 2.382 & 0.029 \\
\hline
\end{tabular}

\section{Discussion}

Because of the ease and speed of analyses, great sensitivity and wide applicability across taxonomic groups, nu- cleic acid contents have been widely applied as a proxy for evaluating nutritional condition (e.g., Wagner et al. 1998, Becker et al. 2005), egg production (e.g., Nakata et al. 1994, Biegala et al. 1999, Speekman et al. 2007, Holmborn et al. 2009), and metabolic rates (e.g., Ikeda et al. 2007, Holmborn et al. 2009, Kobari et al. 2013). In particular, individual contents of nucleic acids and their ratio are known to be representative of growth for some taxonomic groups (e.g., Gusmão \& McKinnon 2011, Gorokhova et al. 2014). Indeed, previous studies have demonstrated that individual contents of nucleic acids and their ratio could be a proxy for weight-specific growth in crustaceans (Dagg \& Littlepage 1972, Båmsted \& Skjoldal 1980, Ota \& Landry 1984, Wagner et al. 2001, Vrede et al. 2002, Yebra et al. 2011). However, a species-specific calibration would be required for this approach when individual contents of nucleic acids and their ratio vary among species and life stages (e.g., Gorokhova \& Kyle 2002, Ikeda et al. 2007).

In the present study, great variability was found in temporal changes in DW and AFDW (Fig. 1). The mixture of different developmental stages present on the incubation day (see Materials and Methods) probably reflects different development rates within the cohort, and is likely responsible for the high variability of the temporal changes in DW and AFDW. Such variability was also observed for the ontogenetic pattern of DW and AFDW (Fig. 2), indicating the presence of variable body weights within the same developmental stage. For many crustaceans, body weights generally increase with developmental stage and molting cycles (e.g., Dagg \& Littlepage 1972, Ota \& Landry 1984, 

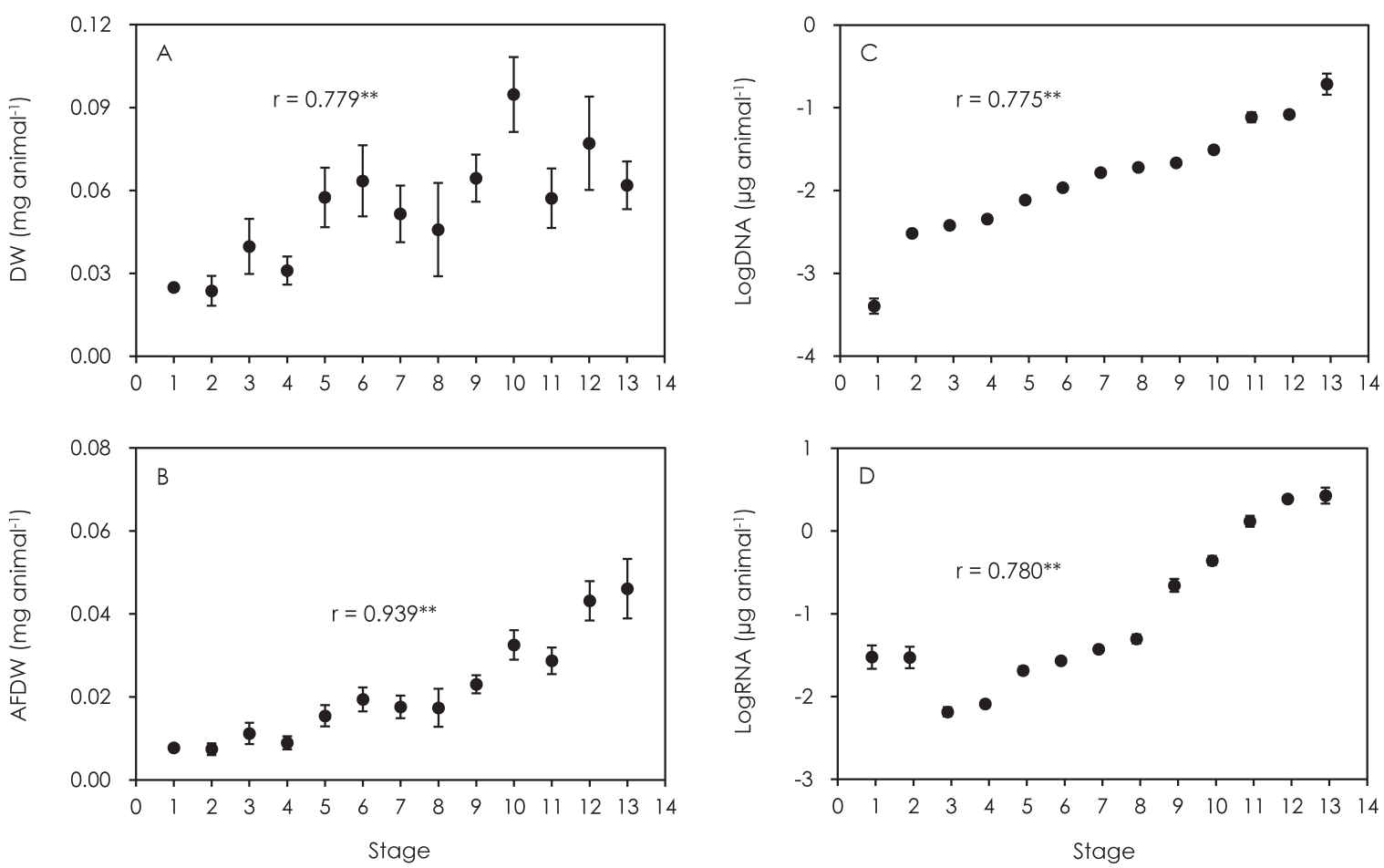

Fig. 2. Ontogenetic changes in dry weight (DW: A), ash-free dry weight (AFDW: B) and individual contents of DNA (C) and RNA (D) of Artemia salina during incubation. Note that individual contents of DNA and RNA are log-transformed. Bars represent the standard error (SE) of the mean. $\mathrm{r}$ : Pearson correlation coefficient. ${ }^{* *}: p<0.01$.
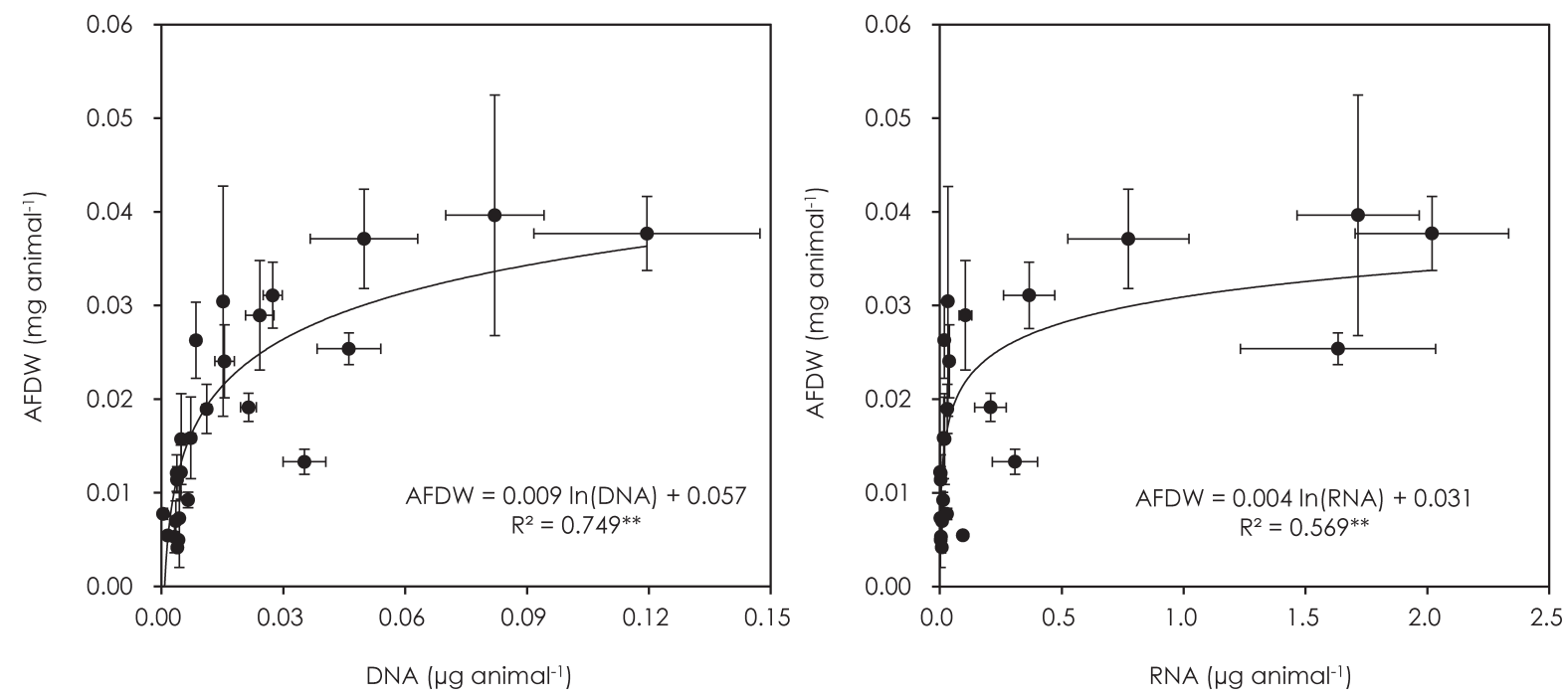

Fig. 3. Scatter plots of ash free dry weight (AFDW) to individual contents of DNA (left) and RNA (right) for Artemia salina over the incubation. The logarithmic regression curves and equations are superimposed. All regression equations were significant. $\mathrm{R}^{2}$ : coefficient of determination. ${ }^{* *}: p<0.01$.

Gorokhova \& Kyle 2002). Based on direct measurements of dry weight, however, newly molted crustaceans are sometimes lighter than animals in the previous stage due to the exuvia (e.g., Shreeve \& Ward 1998). In our results, variations were more pronounced for the ontogenetic patterns in DW than in AFDW, indicating that the high variability reflects different ages within the same stage (i.e., different molting rates). Such variability during a molting cycle could also be significant with respect to the ontogenetic increases in nucleic acid contents due to their linear increase, as with body mass (Gorokhova \& Kyle 2002). However, during the present study, variability was negligible for the ontogenetic patterns of individual DNA and RNA content due to their exponential increases, and this is 

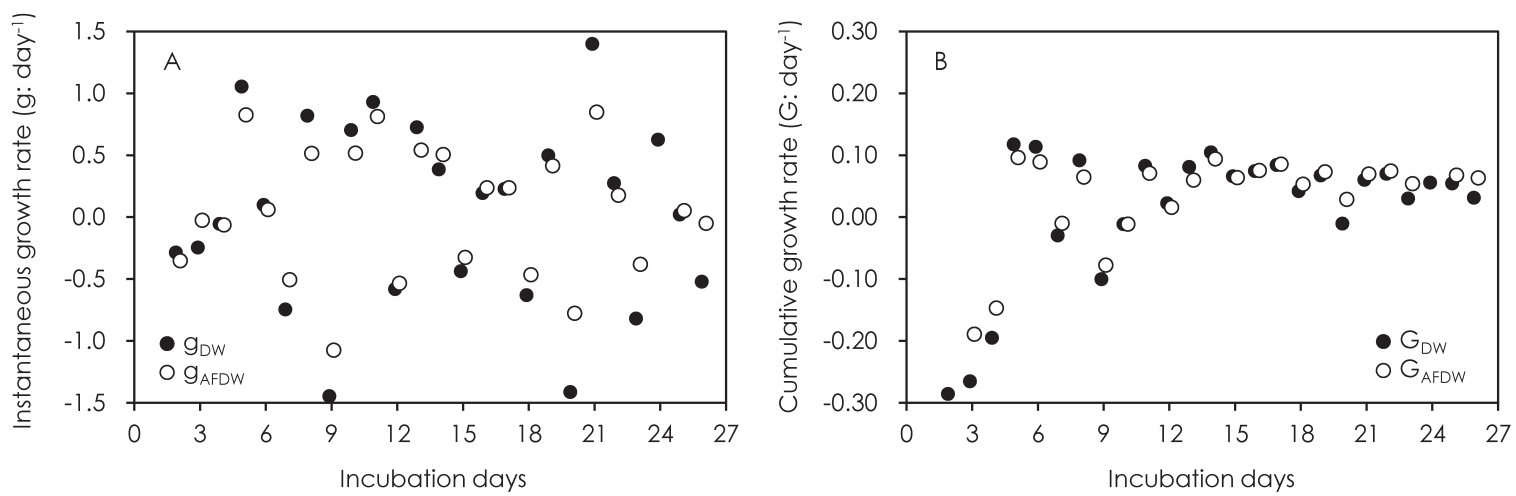

Fig. 4. Temporal changes in instantaneous growth rate (A: $g_{D W}$ and $\left.g_{A F D W}\right)$ and growth increment $\left(B\right.$ : $G_{D W}$ and $\left.G_{A F D W}\right)$ estimated with dry weight (closed circles) and ash free dry weight (open circles) in Artemia salina.
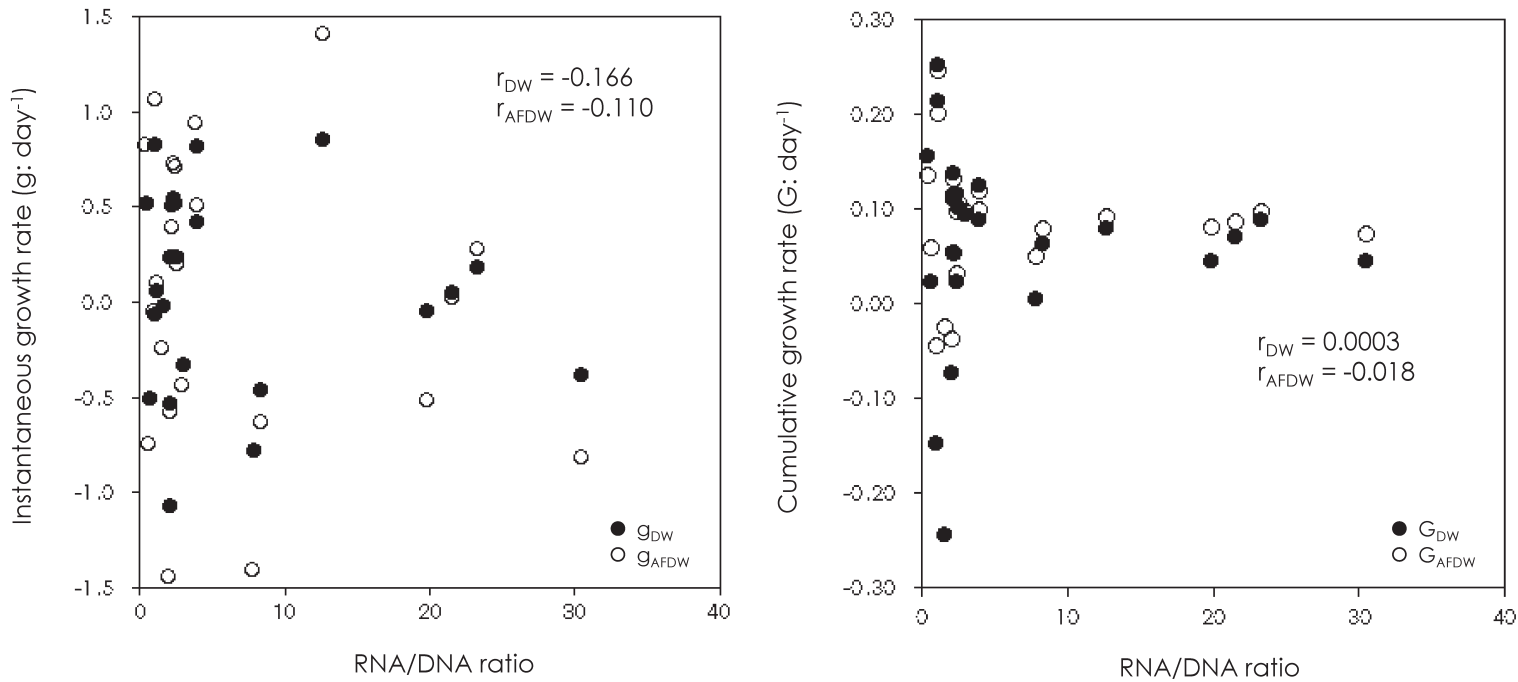

Fig. 5. Scatter diagrams of instantaneous $\left(g_{\mathrm{DW}}\right.$ and $\mathrm{g}_{\mathrm{AFDW}}$ : day $\left.{ }^{-1}\right)$ and cumulative growth rate $\left(\mathrm{G}_{\mathrm{DW}}\right.$ and $\mathrm{G}_{\mathrm{AFDW}}$ : day $\left.{ }^{-1}\right)$ to $\mathrm{RNA} / \mathrm{DNA}$ ratios for Artemia salina from 2 days after egg-hatching. $r$ : Pearson correlation coefficient for $\mathrm{g}_{\mathrm{DW}}\left(\mathrm{r}_{\mathrm{DW}}\right)$ and $\mathrm{g}_{\mathrm{AFDW}}\left(\mathrm{r}_{\mathrm{AFDW}}\right)$. All correlation coefficients were not significant $(p>0.05)$.
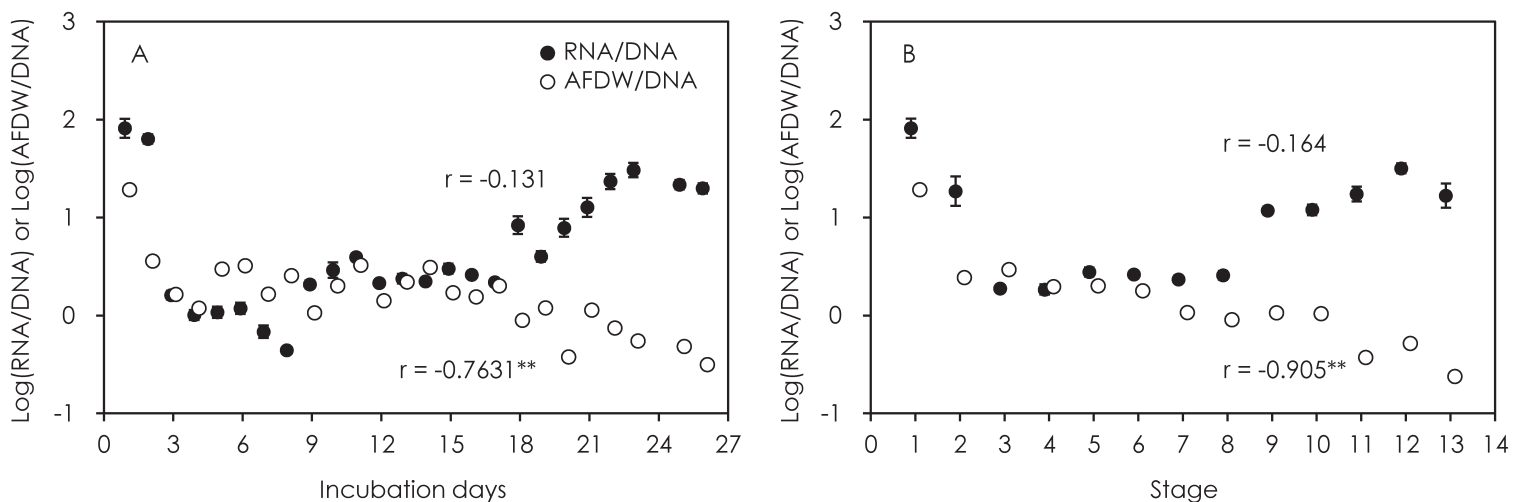

Fig. 6. Temporal (A) and ontogenetic changes (B) in individual contents of RNA to those of DNA (RNA/DNA: closed circles) and AFDW to individual content of DNA (AFDW/DNA: open circles) in Artemia salina. Note that RNA/DNA and AFDW/DNA ratios are log-transformed. Bars represent the standard error (SE) of the mean. Note that Stage 13 is adult.

consistent with previous results for Artemia salina (Dagg \& Littlepage 1972) and Calanus finmarchicus (Wagner et al. 2001). Therefore, the nucleic acid contents of individu- als can be a better proxy for crustacean developmental stage than individual body mass, because of its high variability. 
In the present study, no significant correlation was found for weight-specific growth rates to RNA/DNA ratios (Fig. 5). This might have been a result of the high variability in individual body mass due to the different molting rate. However, our findings suggest several cautions for the practical use of nucleic acid contents as a proxy for growth. First, nucleic acid ratios might be insufficient to evaluate growth for early life stages. As shown in our experiments (Fig. 3), the logarithmic increase in body mass to both DNA and RNA content makes it difficult to accurately asses differences in body mass in early developmental stages. Gorokhova \& Kyle (2002) demonstrated high RNA/ DNA ratios at early embryonic stages for cladocerans and mentioned that this may reflect utilization of lipid energy reserves to support embryonic metabolism. Since proteolytic activities increase with yolk degradation during the first 60 hours after egg hatching in Artemia (Slegers 1991), the high RNA/DNA ratios found in our incubations might be associated with yolk degradation. Second, the ratio of nucleic acids might not be reflective of growth for late life stages with maturing gonads. During the middle to late developmental stages, AFDW/DNA ratios showed a decline while there was an increase in RNA/DNA ratios (Fig. 6). Since the body mass to DNA content ratio of individuals is correlated with cell size (Gorokhova \& Kyle 2002), our findings suggest that cells are downsizing under high growth rates from mid- to late developmental stages. Since the genital structures develop from the late metanauplius stages (Slegers 1991), gonad maturation might be responsible for the inconsistent ontogenetic variations in RNA/ DNA and AFDW/DNA ratios.

In the present study, we demonstrated that individual contents of nucleic acids could be used as a proxy for development, even though there was high variability in individual body masses due to the different molting rates. While nucleic acid ratios were not optimal for the evaluation of weight-specific growth rates with such a high variability in crustacean body mass, a combination of RNA/ DNA and AFDW/DNA ratios could be used to identify important stages in ontogenetic development, such as yolk consumption of newly hatched nauplii and gonad maturation of late life stages in A. salina.

\section{Acknowledgements}

We thank Drs. L. Yebra and A. Sastri for valuable comments and preliminary English correction of the manuscript. We also are grateful for the valuable comments and suggestions from two anonymous reviewers. A part of the present study was supported by grants from the Japan Society for the Promotion of Science (25340011), Ministry of Education, Culture, Sports, Science and Technology, Japan (SKED: The Study of Kuroshio Ecosystem Dynamics for Sustainable Fisheries) and from Kagoshima University.

\section{References}

Båmstedt U, Skjoldahl HR (1980) RNA concentration of zooplankton: relationship with size and growth. Limnol Oceanogr 25: 304-316.

Becker C, Brepohl D, Feuctmayr H, Zöllner E, Sommer F, Clemmesen C, Sommer U, Boersma M. (2005) Impacts of copepods on marine seston, and resulting effects on Calanus finmarchicus RNA:DNA ratios in mesocosm experiments. Mar Biol 146: 531-541.

Berggreen U, Hansen B, Kiørboe T (1988) Food size spectra, ingestion and growth of the copepod during development: Implications for determination of copepod production. Mar Biol 99: 341-352.

Biegala IC, Harris, RP, Bergeron JP (1999) ATCase activity, RNA:DNA ratio, gonad development stage, and egg production in the female copepod Calanus helgolandicus. Mar Biol 135: 1-10.

Burkill PH, Kendall TF (1982) Production of the copepod Eurytemora affinis in the Bristol Channel. Mar Ecol Prog Ser 7: 21-31.

Criel GRJ (1991) Ontogeny of Artemia. In: Browne RA, Sorgeloos P, Clive NA, Trotman CNA (ed) Artemia Biology. CRC Press, London, pp 155-185.

Dagg MJ, Littlepage JL (1972) Relationships between growth rate and RNA, DNA, protein and dry weight in Artemia salina and Euchaeta elongata. Mar Biol 17: 162-170.

Gorokhova E, Kyle M (2002) Analysis of nucleic acids in Daphnia: Development of methods and ontogenetic variations in RNA-DNA content. J Plankton Res 24: 511-522.

Gorokhova E, Hajdu S, Larsson U (2014) Responses of phyto- and zooplankton communities to Prymnesium polylepis (Prymnesiales) bloom in the Baltic Sea. PLoS ONE 9: e112985.

Gusmão LFM, McKinnon AD (2011) Nucleic acid indices of egg production in the tropical copepod Acartia sinjiensis. J Exp Mar Biol Ecol 396: 122-137.

Heinle DR (1966) Production of calanoid copepod, Acartia ton$s a$, in the Patuxent River estuary. Chesapeake Sci 7: 59-74.

Hirst AG, McKinnon AD (2001) Does egg production represent adult female copepod growth? A call to account for body weight changes. Mar Ecol Prog Ser 223: 179-199.

Hirst AG, Peterson WT, Rothery P (2005) Errors in juvenile copepod growth rate estimates are widespread: Problems with the Moult Rate method. Mar Ecol Prog Ser 296: 263-279.

Holmborn T, Dahlgren K, Holeton C, Hogfors H, Gorokhova E (2009) Biochemical proxies for growth and metabolism in Acartia bifilosa (Copepoda, Calanoida). Limnol Oceanogr Methods 7: 785-794.

Ikeda T, Motoda S (1978) Estimated zooplankton production and their ammonia excretion in the Kuroshio and adjacent Seas. Fish Bull 76: 357-367.

Ikeda T, Sano F, Yamaguchi A, Matsuishi T (2007) RNA:DNA ratios of calanoid copepods from the epipelagic through abyssopelagic zones of the North Pacific Ocean. Aquat Biol 1: 99108.

Kimmerer WJ (1987) The theory of secondary production calculations for continuously reproducing populations. Limnol Oceanogr 32: 1-13. 
Kimmerer WJ, McKinnon AD (1983) Growth, mortality and secondary production of the copepod Acartia tranteri in Westernport Bay, Australia. Limnol Oceanogr 32: 14-28.

Kimmerer WJ, Hirst AG, Hopcroft RR, McKinnon AD (2007) Estimating juvenile copepod growth rates: corrections, intercomparisons and recommendations. Mar Ecol Prog Ser 336: 187-202.

Kobari T (2010) Measurements of growth rate for natural population of planktonic copepods: a review. Oceanogr Japan 19: 213-232.

Kobari T, Mori H, Tokushige H (2013) Nucleic acids and protein content in ontogenetically migrating copepods in the Oyashio region as influenced by development stage and depth distribution. J Plankton Res 35: 105-120.

Lavens P, Sorgeloos P (1991) Production of Artemia in culture tanks. In: Browne RA, Sorgeloos P, Clive NA, Trotman CNA (ed) Artemia Biology. CRC Press, London, pp 317-350.

Nakata K, Nakano H, Kikuchi H (1994) Relationship between egg productivity and RNA/DNA ratio in Paracalanus sp. in the frontal waters of the Kuroshio. Mar Biol 119: 591-596.

Oosterhuis SS, Baars MA, Klein-Breteler WCM (2000) Release of the enzyme chitobiase by the copepod Temora longicornis: characteristics and potential tool for estimating crustacean biomass production in the sea. Mar Ecol Prog Ser 196: 195-206.

Ota AY, Landry MR (1984) Nucleic acids as growth rate indicators for early developmental stages of Calanus pacificus Brodsky. J Exp Mar Biol Ecol 80: 147-160.

Postel L, Fock H, Hagen W (2000) Biomass and abundance. In: Harris RP, Wiebe PH, Lenz J, Skjoldal HR, Huntley M (ed) Zooplankton Methodology Manual. Academic Press, London, pp 83-192.

Sastri AR, Roff JC (2000) Rate of chitobiase degradation as a measure of development rate in planktonic crustacea. Can Fish
Aquat Sci 57: 1965-1968.

Slegers H (1991) Enzyme activities through development: A synthesis of the activity and control of the various enzymes as the embryo matures. In: Browne RA, Sorgeloos P, Clive NA, Trotman CNA (ed) Artemia Biology. CRC Press, London, pp $37-73$.

Shreeve RS, Ward P (1998) Moulting and growth of the early stages of two species of Antarctic calanoid copepod in relation to differences in food supply. Mar Ecol Prog Ser 175: 175-109.

Speekman CL, Nunez BS, Busjey JE (2007) Measuring RNA:DNA ratios in individual Acartia tonsa (Copepoda). Mar Biol 151: 759-766.

Vrede T, Persson J, Aronsen G (2002) The influence of food quality (P:C ratio) on RNA:DNA ratio and somatic growth rate of Daphnia. Limnol Oceanogr 47: 487-494.

Wagner MM, Durbin EG, Buckley LJ (1998) RNA:DNA ratios as indicators of nutritional condition in the copepod Calanus finmarchicus. Mar Ecol Prog Ser 162: 173-181.

Wagner MM, Campbell RG, Boudreau CA, Durbin EG (2001) Nucleic acids and growth of Calanus finmarchicus in the laboratory under different food and temperature conditions. Mar Ecol Prog Ser 221: 185-197.

Williamson CE, Butler N, Forcina L (1985) Food limitation in naupliar and adult Diaptomus pallidus. Limnol Oceanogr 30: 1283-1290.

Yebra L, Hernádez-León S (2004) Aminoacyl-tRNA synthetase as a growth index in zooplankton. J Plankton Res 26: 351-356.

Yebra L, Harris RP, Smith AT (2005) Comparison of five methods for estimating growth of Calanus helgolandicus later developmental stages (CV-CVI). Mar Biol 147: 1367-1375.

Yebra L, Berdalet E, Almeda R, Pérez V, Calbet A, Saiz E (2011) Protein and nucleic acid metabolism as proxies for growth and fitness of Oithona davisae (Copepoda, Cyclopoida) early developmental stages. J Exp Mar Biol Ecol 406: 87-94. 